\title{
Teaching NeuroImages: Spinal subdural hematoma in pediatric nonaccidental trauma
}

Christopher S. Hong, MD, Joaquin Camara-Quintana, MD, Adam J. Kundishora, MD, Michael L. Diluna, MD, and Kristopher T. Kahle, MD, PhD

Neurology ${ }^{\circledR}$ 2019;93:e522-e523. doi:10.1212/WNL.0000000000007869

A 5-month-old boy had bilateral intracranial subdural hematomas from nonaccidental trauma with a poor neurologic examination limited to extremity withdrawal. Spinal imaging (figure) demonstrated a subdural hematoma spanning T4-L5 with cord compression. He underwent L3-5 laminectomies, durotomy, and subdural irrigation, resulting in excellent evacuation of cephalad blood products. Postoperatively, he developed CSF leakage, prompting burr-hole drainage of intracranial subdural hematomas to relieve

\section{Correspondence}

Dr. Kahle

kristopher.kahle@yale.edu

MORE ONLINE

\section{$\rightarrow$ Teaching slides}

links.lww.com/WNL/

A934

Figure Imaging

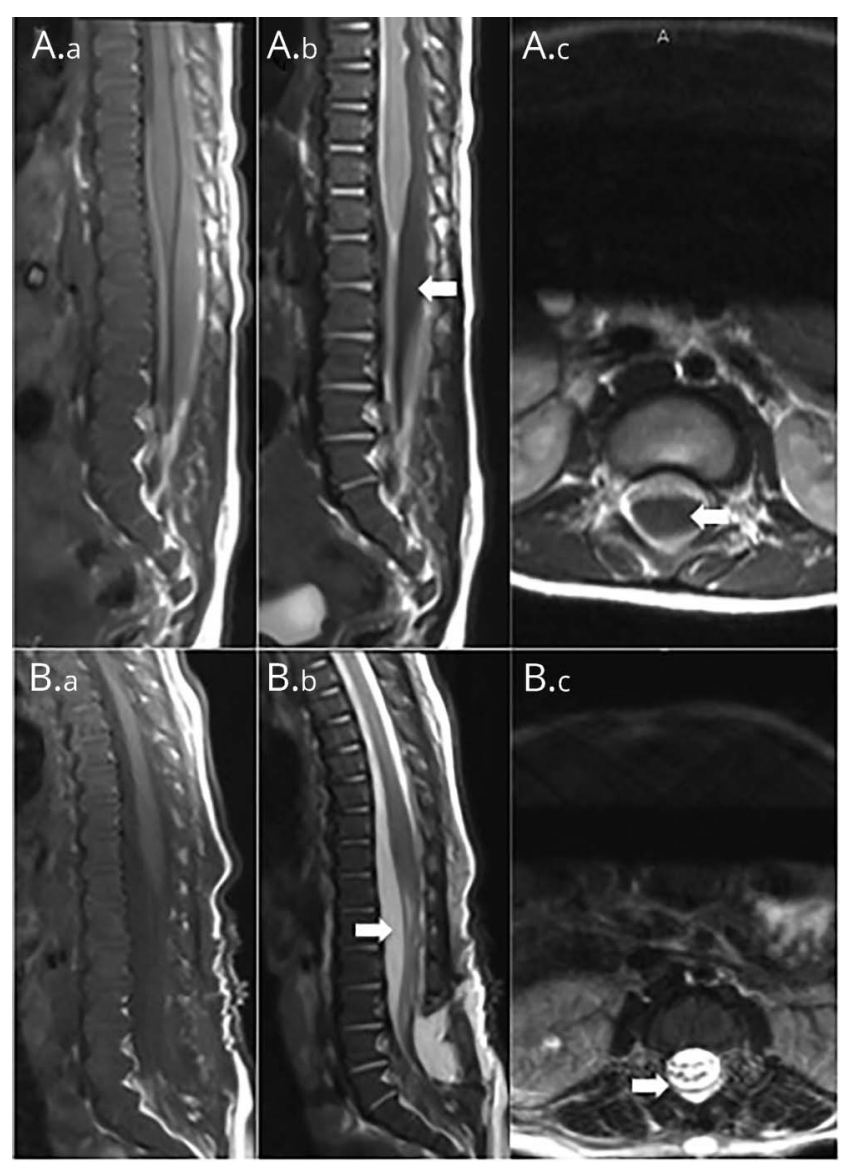

Sagittal T1-MRI (A.a) preoperatively and (B.a) postoperatively, T2-MRI (A.b) preoperatively and (B.b) postoperatively, and axial T2-MRI through L1-2 disc space (A.C) preoperatively and (B.C) postoperatively demonstrates T2-hypointense subdural hemorrhage (arrows in A.b and A.C) causing thecal sac effacement with resolved compression and restoration of T2-hyperintense CSF signal (arrows in B.b and B.c) postoperatively.

From the Department of Neurosurgery, Yale University School of Medicine, New Haven, CT.

Go to Neurology.org/N for full disclosures. Funding information and disclosures deemed relevant by the authors, if any, are provided at the end of the article. 
a suspected pressure gradient between brain and spine. Subdural spinal hematomas are underrecognized but highly morbid injuries that may warrant further imaging workup in cases of severe intracranial injury or poor neurologic examination in suspected nonaccidental trauma. $^{1,2}$

\section{Author contributions}

C. Hong: drafting/revising the manuscript, data acquisition, study concept or design, analysis or interpretation of data, accepts responsibility for conduct of research and final approval, acquisition of data, study supervision. J. CamaraQuintana: drafting/revising the manuscript, analysis or interpretation of data, accepts responsibility for conduct of research and final approval, study supervision. A.J. Kundishora: drafting/revising the manuscript, accepts responsibility for conduct of research and final approval. M.L. Diluna: drafting/revising the manuscript, data acquisition, study concept or design, analysis or interpretation of data, accepts responsibility for conduct of research and final approval, acquisition of data, study supervision. K.T. Kahle: drafting/revising the manuscript, data acquisition, study concept or design, analysis or interpretation of data, accepts responsibility for conduct of research and final approval, study supervision.

\section{Study funding}

No targeted funding reported.

\section{Disclosure}

The authors report no disclosures relevant to the manuscript. Go to Neurology.org/N for full disclosures.

\section{References}

1. Choudhary AK, Bradford RK, Dias MS, Moore GJ, Boal DK. Spinal subdural hemorrhage in abusive head trauma: a retrospective study. Radiology 2012;262:216-223.

2. Gunda D, Cornwell BO, Dahmoush HM, Jazbeh S, Alleman AM. Pediatric central nervous system imaging of nonaccidental trauma: beyond subdural hematomas. Radiographics 2018;23:180084. 


\section{Neurology}

\section{Teaching NeuroImages: Spinal subdural hematoma in pediatric nonaccidental trauma Christopher S. Hong, Joaquin Camara-Quintana, Adam J. Kundishora, et al.}

Neurology 2019;93;e522-e523

DOI 10.1212/WNL.0000000000007869

This information is current as of July 29, 2019

\section{Updated Information \& Services}

References

Subspecialty Collections

Permissions \& Licensing

Reprints including high resolution figures, can be found at: http://n.neurology.org/content/93/5/e522.full

This article cites 2 articles, 0 of which you can access for free at: http://n.neurology.org/content/93/5/e522.full\#ref-list-1

This article, along with others on similar topics, appears in the following collection(s):

All Pediatric

http://n.neurology.org/cgi/collection/all_pediatric

Brain trauma

http://n.neurology.org/cgi/collection/brain_trauma

Spinal cord trauma

http://n.neurology.org/cgi/collection/spinal_cord_trauma

Information about reproducing this article in parts (figures,tables) or in its entirety can be found online at:

http://www.neurology.org/about/about_the_journal\#permissions

Information about ordering reprints can be found online:

http://n.neurology.org/subscribers/advertise

Neurology ${ }^{\circledR}$ is the official journal of the American Academy of Neurology. Published continuously since 1951, it is now a weekly with 48 issues per year. Copyright (O 2019 American Academy of Neurology. All rights reserved. Print ISSN: 0028-3878. Online ISSN: 1526-632X.

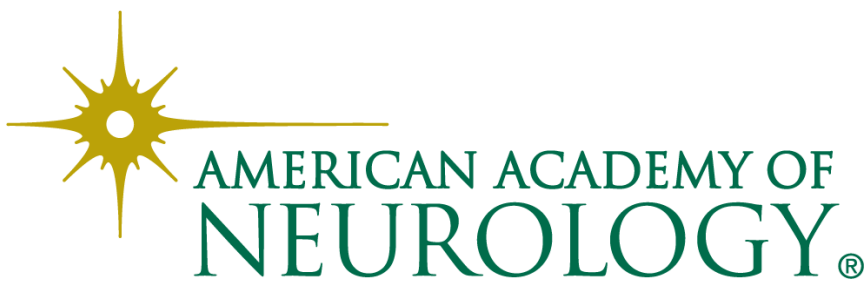

